\title{
Prognostic significance of circulating lymphocyte subsets in patients with nasopharyngeal carcinoma
}

\section{Research Article}

Keywords:

Posted Date: January 12th, 2022

DOI: https://doi.org/10.21203/rs.3.rs-673390/v2

License: (a) (i) This work is licensed under a Creative Commons Attribution 4.0 International License. Read Full License 


\section{Abstract}

The full text of this preprint has been withdrawn by the authors while they make corrections to the work. Therefore, the authors do not wish this work to be cited as a reference. Questions should be directed to the corresponding author.

Additionally, the authors have provided this withdrawal declaration: "In this preprint, the criteria for inclusion and exclusion of study designs were not rigorous enough. After data verification, we found that there were some missing or unknown people in the follow-up results of the original data. This part of data may cause information bias. we recognize that the results and conclusions obtained based on these data may be unreliable. After careful discussion, all authors have agreed that, based on the need of scientific accuracy and honesty, it is necessary to withdraw the preprint."

\section{Full Text}

The authors have withdrawn this preprint from Research Square. 